\title{
Correction to: Genetic structure and diversity of the mustard hill coral Porites astreoides along the Florida Keys reef tract
}

\author{
Dominique N. Gallery ${ }^{1,2,3} \cdot$ Michelle L. Green $^{2} \cdot$ Ilsa B. Kuffner ${ }^{1} \cdot$ Elizabeth A. Lenz $^{4,5} \cdot$ Lauren T. Toth $^{1}$ \\ Published online: 6 August 2021 \\ (c) Senckenberg Gesellschaft für Naturforschung 2021
}

\section{Correction to Marine Biodiversity}

https://doi.org/10.1007/s12526-021-01196-7

In the original version of this article, affiliation details for Elizabeth A. Lenz were incorrectly given as:

4 Hawai'i Institute of Marine Biology, University of Hawai'i, Mānoa 96744, USA

5 Sea Grant College Program, University of Hawai'i At Mānoa, Mānoa 96822, USA.

The correct affiliations are:

4 Hawai' $i$ Institute of Marine Biology, University of Hawai' $i$ at Mānoa, Kāne'ohe, 96744, USA

5 University of Hawai'i Sea Grant College Program, University of Hawai' $i$ at Mānoa, Honolulu, 96822, USA

Publisher's note Springer Nature remains neutral with regard to jurisdictional claims in published maps and institutional affiliations.

The original article can be found online at https://doi.org/10.1007/ s12526-021-01196-7.

\section{Dominique N. Gallery}

US Geological Survey St. Petersburg Coastal and Marine Science Center, St. Petersburg 33701, USA

2 University of South Florida, St. Petersburg 33701, USA

3 Department of Integrative Biology, The University of Texas at Austin, Austin 78712, USA

4 Hawai 'i Institute of Marine Biology, University of Hawai' $i$ at Mānoa, Kāne'ohe 96744, USA

5 University of Hawai' $i$ Sea Grant College Program, University of Hawai‘i at Mānoa, Honolulu 96822, USA 